\title{
Production of Feruloyl Esterase from Aspergillus niger by Solid-State Fermentation on Different Carbon Sources
}

\author{
Shiyi Ou, Jing Zhang, Yong Wang, and Ning Zhang \\ Department of Food Science and Engineering, Jinan University, Guangzhou 510632, China \\ Correspondence should be addressed to Shiyi Ou, tosy@jnu.edu.cn
}

Received 20 December 2010; Accepted 7 February 2011

Academic Editor: Alane Beatriz Vermelho

Copyright ( 2011 Shiyi Ou et al. This is an open access article distributed under the Creative Commons Attribution License, which permits unrestricted use, distribution, and reproduction in any medium, provided the original work is properly cited.

A mixture of wheat bran with maize bran as a carbon source and addition of $\left(\mathrm{NH}_{4}\right) \mathrm{SO}_{4}$ as nitrogen source was found to significantly increase production of feruloyl esterase (FAE) enzyme compared with wheat bran as a sole carbon and nitrogen source. The optimal conditions in conical flasks were carbon source $(30 \mathrm{~g})$ to water $1: 1$, maize bran to wheat bran $1: 2,\left(\mathrm{NH}_{4}\right) \mathrm{SO}_{4}$ $1.2 \mathrm{~g}$ and $\mathrm{MgSO}_{4} 70 \mathrm{mg}$. Under these conditions, FAE activity was $7.68 \mathrm{mU} / \mathrm{g}$. The FAE activity on the mixed carbon sources showed, high activity against the plant cell walls contained in the cultures.

\section{Introduction}

Feruloyl esterases (FAEs; E.C. 3.1.1.73) are the enzymes responsible for cleaving the ester link between polysaccharides and monomeric or dimeric ferulic acid. This enzyme activity liberates phenolic acids (ferulic acid (FA) and pcoumaric acid) and their dimers from naturally occurring hemicelluloses and pectins $[1,2]$. FAE has applications in the food, feed, and pharmaceutical industries, as well as in fuel production. Firstly, this enzyme can release ferulic acid from agrobyproducts, which can be used as antioxidants $[1,3]$ and transformed into other valuable molecules such as styrenes, polymers, epoxides, alkylbenzenes, vanillic acid derivatives, protocatechuric acid-related catechols, guaiacol, catechol, and vanillin [4]; secondly, FAE digestion can allow recovery of a number of phenolic compounds from nonwood fibers, such as wheat straw, rice straw, and sugarcane baggasse, while freeing up the resulting cellulose fibers for use in papermaking [5]; thirdly, the enzyme has synergistic effects on cellulase and xylanase activities for release of glucose and xylose from cellulose and hemicellulose for ethanol production $[1,6]$; fourthly, FAE acts as a biosynthetic tool for formation of more lipophilic antioxidant derivatives [1]; fifthly, FAE has been used to improve the in vitro bioaccessibility and colonic metabolism of phenolic compounds in humans and to increase digestion of complex plant cell walls in animals $[1,7]$.
Many microorganisms have been reported to produce FAE. Among these, Aspergillus species, such as Aspergillus flavipes, Aspergillus awamori, Aspergillus niger, and Aspergillus oryzae, are the most active producers of feruloyl esterases [8-11]. In this research, A. niger was used to investigate the production of feruloyl esterases by solid fermentation on different substrates.

\section{Materials and Methods}

2.1. Materials. Wheat bran was purchased from Nanfang Flour Co. Ltd., (Guangzhou, China), maize bran was obtained from Huabei Pharmaceutical Company (Hebei, China), and sugarcane bagasse from Overseas Chinese Sugar Processing Company (Taishan, Guangdong Province, China). All of these substrates were dried in an oven at $105^{\circ} \mathrm{C}$ to constant weight, and sugarcane bagasse was ground to pass a 45-mesh sieve.

Commercial $\alpha$-amylase (20000 U/g) was purchased from NOVO, Bagsvaerd, Denmark and papain $(600000 \mathrm{U} / \mathrm{g})$ from Yuantian Enzymes Company (Guangzhou, China); transferulic acid (98\%) was purchased from Shanghai Chemical Reagents Company (Shanghai, China). All other chemicals and solvents used were of analytical grade.

Aspergillus niger (ATCC16404) was purchased from Guangzhou Huankai Chemical Reagents Company 
(Guangzhou, China) and preserved on potato dextrose agar (PDA) at $4^{\circ} \mathrm{C}$ for storage.

2.2. Preparation of Destarched Wheat Bran, Maize Bran, and Sugarcane Bagasse. Wheat bran, maize bran, and sugarcane bagasse were destarched for determination of enzyme activity according to Mukherjee et al. [12]. Essentially, this consisted of treatment with $0.30 \%(\mathrm{w} / \mathrm{v})$ potassium acetate at $95^{\circ} \mathrm{C}$ for $30 \mathrm{~min}$, followed by extensive washing with water to remove starch.

2.3. Effect of Different Carbon Sources on Production of Feruloyl Esterase. $30 \mathrm{~g}$ of wheat bran was added to a $250 \mathrm{ml}$ of conical flask with $50 \mathrm{mg}$ of $\mathrm{MgSO}_{4}$ dissolved in $60 \mathrm{ml}$ of water and autoclaved at $121^{\circ} \mathrm{C}$ for $25 \mathrm{~min}$ and cooled to room temperature. A $1 \mathrm{ml}$ volume of spore suspension $\left(2 \times 10^{8}\right.$ spores $/ \mathrm{ml}$, counted using a haemocytometer $)$ was inoculated, and samples were incubated at constant temperature $\left(30,32,34\right.$, or $\left.36^{\circ} \mathrm{C}\right)$ for 2 to 5 days.

Culture of A. niger on $30 \mathrm{~g}$ of sugarcane bagasse or maize bran at $36^{\circ} \mathrm{C}$ for 2 to 5 days was carried out as described above.

2.4. Effect of Mixture of Carbon and Nitrogen Sources on Production of Feruloyl Esterase. $1.2 \mathrm{~g}$ of $\left(\mathrm{NH}_{4}\right)_{2} \mathrm{SO}_{4}, \mathrm{NH}_{4} \mathrm{NO}_{3}$, $\mathrm{NaNO}_{3}$, and urea were, respectively, added as nitrogen source to test the effect on production of FAE by A. niger in the mixture substrate of wheat bran with maize bran or sugarcane bagasse.

$30 \mathrm{~g}$ of wheat bran and different mixtures of wheat bran with sugarcane bagasse or with maize bran was added into a $250 \mathrm{ml}$ of conical flask with $50 \mathrm{mg}$ of $\mathrm{MgSO}_{4}$ dissolved in $60 \mathrm{ml}$ of water and autoclaved at $121^{\circ} \mathrm{C}$ for $25 \mathrm{~min}$ and cooled to room temperature; $1 \mathrm{ml}$ of spore suspension $(2 \times$ $10^{8} \mathrm{spores} / \mathrm{ml}$ ) was inoculated and kept in an incubator at $t$ $36^{\circ} \mathrm{C}$ for 3 days.

2.5. Orthogonal Test. According to orthogonal table $\mathrm{L}_{9}\left(3^{4}\right)$, four operation parameters with three levels were arranged (Table 1).

2.6. Enzyme Extraction. After suitable culture periods, the FAE enzyme was extracted. The fermented substrates were extracted three times with $100 \mathrm{ml}$ of distilled water by shaking $(150 \mathrm{rpm})$ at room temperature for $20 \mathrm{~min}$. Solids were then separated from the solution by filtering through a 200-mesh nylon cloth sieve. The solutions were combined and centrifuged at $10,000 \mathrm{~g}$ for $20 \mathrm{~min}$ at $4^{\circ} \mathrm{C}$ using a refrigerated centrifuge (TGL-16G-A, Shanghai Jiapeng Science and Technology Instrument Company, Shanghai, China). The clarified supernatant was diluted with distilled water to $500 \mathrm{ml}$ and kept at $4^{\circ} \mathrm{C}$ in a refrigerator.

2.7. Determination of Ferulic Acid by HPLC. Ferulic acid from wheat bran, maize bran, and sugarcane bagasse was extracted according to the method of [13] and determined with an Agilent 1100 Series high-performance liquid chromatograph (Waldbronn, Germany) equipped with a diode

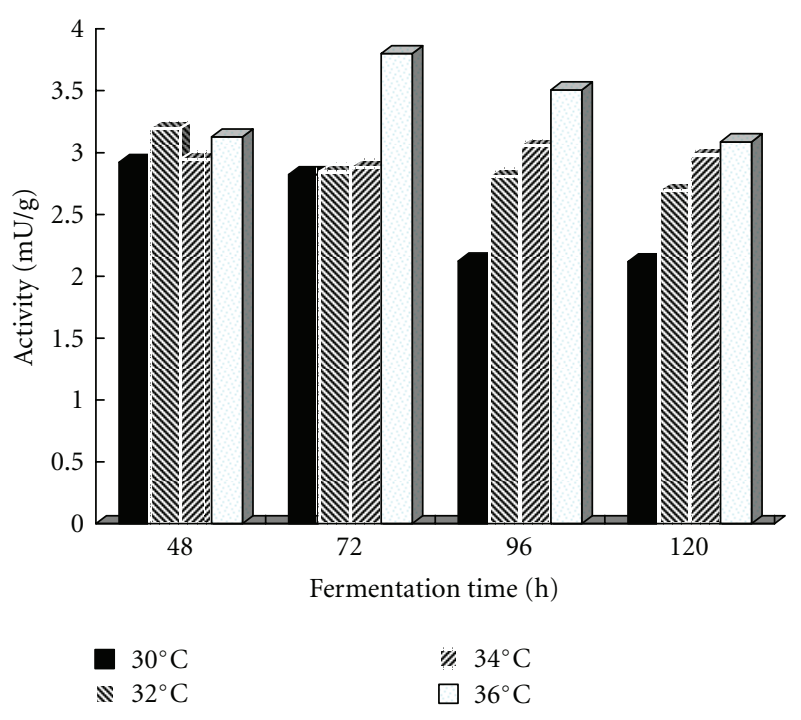

Figure 1: Effect of fermentation time and temperature on feruloyl esterase production.

array detector and an Eclipse XDB-C18 column (4.6 mm $\times$ $250 \mathrm{~mm}, 5 \mu \mathrm{m}$ ). The temperature of the column oven was set at $40^{\circ} \mathrm{C}$. The injection volume was $10 \mu \mathrm{L}$. Elution was carried out using an isocratic system consisting of $1 \%$ acetic acid: methanol $(72: 28)$ at $1 \mathrm{~mL} / \mathrm{min}$. Ferulic acid was detected at $313 \mathrm{~nm}$, with authentic ferulic acid as standard.

2.8. Enzyme Assay. Feruloyl esterase activity was assayed by analysis of free ferulic acid released from de-starched wheat bran (DSWB) according to Mukherjee et al. [12] with slight modification. The reaction mixture contained $100 \mathrm{mg}$ of DSWB and $2.5 \mathrm{ml}$ of enzyme in phosphate buffer $(2.5 \mathrm{ml}$, $70 \mathrm{mM}, \mathrm{pH} 6.0$ ) in a final volume of $5.0 \mathrm{ml}$ (kept in a water bath for $5 \mathrm{~min}$ before DSWB was added) and was incubated for $15 \mathrm{~min}$ at $40^{\circ} \mathrm{C}$. The reaction was stopped by putting the mixture into boiling water for $3 \mathrm{~min}$. After centrifugation $(10,000 \mathrm{~g}, 15 \mathrm{~min})$, the ferulic acid content of the supernatant was determined by HPLC. Feruloyl esterase activity ( $1 \mathrm{mU}$ ) was defined as the enzyme produced by $1 \mathrm{~g}$ of carbon source that released $1 \mu \mathrm{mol}$ ferulic acid per min at $40^{\circ} \mathrm{C}$ and $\mathrm{pH}$ 6.0. Background ferulic acid levels were subtracted during calculations.

The activity of feruloyl esterase produced from A. niger cultured on different carbon sources was also assayed, based on different plant cell wall types.

2.9. Statistical Analysis. Statistics with three replicates were determined using SPSS 13.0 for Windows procedure.

\section{Results and Discussion}

3.1. Effect of Fermentation Time and Temperature on Production of Feruloyl Esterase. Fermentation temperature significantly influenced production of feruloyl esterase (Figure 1), and highest activity of feruloyl esterase was produced from 
TABLE 1: $\mathrm{L}_{9}\left(3^{4}\right)$ orthogonal arrangement.

\begin{tabular}{lcccc}
\hline SN* A. Solid/water & $\begin{array}{c}\text { B. Maize } \\
\text { bran/Wheat } \\
\text { bran }\end{array}$ & $\begin{array}{c}\text { C. }\left(\mathrm{NH}_{4}\right)_{2} \mathrm{SO}_{4} \\
(\mathrm{~g})\end{array}$ & $\begin{array}{c}\text { D. } \mathrm{MgSO}_{4} \\
(\mathrm{mg})\end{array}$ \\
\hline 1 & $1: 1$ & $1: 2$ & 0.6 & 35 \\
2 & $1: 1.5$ & $1: 1$ & 0.9 & 70 \\
3 & $1: 2$ & $3: 2$ & 1.2 & 105 \\
\hline \multicolumn{2}{l}{ " Serial No. }
\end{tabular}

TABle 2: Production of feruloyl esterase from A. niger cultured for $2-5 \mathrm{~d}$ on different carbon source.

\begin{tabular}{lcccc}
\hline & \multicolumn{5}{c}{ Feruloyl esterase activity $(\mathrm{mU} / \mathrm{g})$} \\
$\begin{array}{l}\text { Carbon } \\
\text { source }\end{array}$ & $2 \mathrm{~d}$ & $3 \mathrm{~d}$ & $4 \mathrm{~d}$ & $5 \mathrm{~d}$ \\
\hline $\begin{array}{l}\text { Wheat bran } \\
\text { Maize bran }\end{array}$ & $3.13 \pm 0.08^{*}$ & $3.8 \pm 0.12$ & $3.51 \pm 0.13$ & $3.09 \pm 0.09$ \\
$\begin{array}{l}\text { Sugarcane } \\
\text { bagasse }\end{array}$ & $1.36 \pm 0.11$ & $2.77 \pm 0.08$ & $2.38 \pm 0.13$ & $1.99 \pm 0.07$ \\
${ }^{*}$ means $\pm \mathrm{SD}, n=3$. & $1.47 \pm 0.08$ & $1.15 \pm 0.10$ & $0.97 \pm 0.07$ \\
\end{tabular}

A. niger on wheat bran at $72 \mathrm{~h}$ and $36^{\circ} \mathrm{C}$. Thus, subsequent fermentation experiments were carried out at $36^{\circ} \mathrm{C}$ for $72 \mathrm{~h}$.

3.2. Effect of Carbon and Nitrogen Sources on Production of Feruloyl Esterase. The contents of ferulic acid in the tested wheat bran, sugarcane bagasse, and maize bran were $0.53 \%$, $0.94 \%$, and $1.36 \%$, respectively; protein content in wheat bran, sugarcane bagasse, and maize bran were $12.8 \%, 3.8 \%$, and $7.4 \%$, respectively, by Kjeldahl determination.

Feruloyl esterase is a form of inducible enzyme that is specifically induced by the presence of aromatic compounds [13]. Maize bran and sugarcane bagasse contain more ferulic acid than does wheat bran; these were tested to determine whether higher feruloyl esterase activity could be induced by these carbon sources. Table 2 shows that lower enzyme activity was produced using $A$. niger on maize bran or sugarcane bagasse as the sole nitrogen and carbon source. We postulated that the main reason is that these substrates contained lower nitrogen than did wheat bran; thus, mixtures of maize bran or sugarcane bagasse with wheat bran in different ratios were used as the culture substrate. Much higher enzyme activity was produced on the mixture of wheat bran with maize bran or sugarcane bagasse than with wheat bran as the sole carbon source (Table 3 ). The highest enzyme activity was obtained when $12 \mathrm{~g}$ of wheat bran was mixed with $18 \mathrm{~g}$ of maize bran. Compared with maize bran, a mixture of sugarcane bagasse with wheat bran produced less enzyme than did a mixture of maize bran (Table 3).

Addition of nitrogen to the mixture of carbon sources further increased enzyme activity (Table 4); however, significantly different enzyme activity was achieved with different nitrogen sources. $\left(\mathrm{NH}_{4}\right)_{2} \mathrm{SO}_{4}$ was the best nitrogen source, followed by urea, $\mathrm{NH}_{4} \mathrm{NO}_{3}$, and $\mathrm{NaNO}_{3}$. As a drop occurs in of extracellular $\mathrm{pH}$ during the growth of $A$. niger [14], the
TABLE 3: Effect of different ratio of wheat bran to maize bran or sugarcane bagasse on feruloyl esterase production.

\begin{tabular}{lcc}
\hline & \multicolumn{2}{c}{ Feruloyl esterase activity $(\mathrm{mU} / \mathrm{g})$} \\
Wheat bran $(\mathrm{g})^{*}$ & Maize bran & Sugarcane bagasse \\
\hline 20 & $3.94 \pm 0.12^{* *}$ & $3.91 \pm 0.12$ \\
15 & $4.34 \pm 0.13$ & $4.29 \pm 0.09$ \\
12 & $4.47 \pm 0.14$ & $4.21 \pm 0.14$ \\
10 & $4.19 \pm 0.11$ & $3.73 \pm 0.13$ \\
\hline$*$
\end{tabular}

TABLE 4: Effect of nitrogen source on production of feruloyl esterase in mixtures of wheat bran and maize bran or sugarcane bagasse.

\begin{tabular}{lcccc}
\hline & \multicolumn{4}{c}{ Feruloyl esterase activity $(\mathrm{mU} / \mathrm{g})$} \\
& $1: 1$ & $1: 2$ & $1: 1$ & $1: 2$ \\
\hline $\mathrm{NaNO}_{3}$ & $4.84 \pm 0.15^{* *}$ & $5.43 \pm 0.13$ & $4.43 \pm 0.08$ & $4.62 \pm 0.13$ \\
$\mathrm{NH}_{4} \mathrm{NO}_{3}$ & $4.98 \pm 0.14$ & $5.87 \pm 0.16$ & $4.54 \pm 0.14$ & $4.78 \pm 0.14$ \\
$\mathrm{Urea}$ & $4.76 \pm 0.11$ & $5.09 \pm 0.12$ & $4.52 \pm 0.13$ & $4.12 \pm 0.13$ \\
$\left(\mathrm{NH}_{4}\right)_{2} \mathrm{SO}_{4}$ & $6.23 \pm 0.15$ & $6.78 \pm 0.14$ & $5.32 \pm 0.16$ & $5.86 \pm 0.15$ \\
\hline
\end{tabular}

${ }^{*} \mathrm{~W}$ : wheat bran; S: sugarcane bagasse; M: maize bran. ${ }^{* *}$ means $\pm \mathrm{SD}$, $n=3$.

TABLE 5: Result of the orthogonal test.

\begin{tabular}{lccccc}
\hline Test No & A & B & C & D & FAE activity $(\mathrm{mU} / \mathrm{g})$ \\
\hline 1 & 1 & 1 & 1 & 1 & 6.04 \\
2 & 1 & 2 & 2 & 2 & 6.83 \\
3 & 1 & 3 & 3 & 3 & 7.46 \\
4 & 2 & 1 & 2 & 3 & 5.88 \\
5 & 2 & 2 & 3 & 1 & 5.65 \\
6 & 2 & 3 & 1 & 2 & 4.87 \\
7 & 3 & 1 & 3 & 2 & 6.51 \\
8 & 3 & 2 & 1 & 3 & 4.26 \\
9 & 3 & 3 & 2 & 1 & 5.97 \\
T1 & 20.33 & 18.43 & 15.17 & 17.66 & \\
T2 & 16.4 & 16.74 & 16.68 & 18.21 & \\
T3 & 16.74 & 18.3 & 19.62 & 17.6 & \\
R & 3.93 & 1.69 & 4.45 & 0.61 & \\
\hline
\end{tabular}

use of the acid salt $\left(\mathrm{NH}_{4}\right)_{2} \mathrm{SO}_{4}$ is possibly beneficial for the growth of $A$. niger strains.

\subsection{Optimization of Conditions for Production of Feruloyl} Esterase. The results of an orthogonal test are shown in Table 5. The optimal conditions for production of feruloyl esterase from $A$. niger were carbon source to water $1: 1$, maize bran to wheat bran $3: 2,\left(\mathrm{NH}_{4}\right) \mathrm{SO}_{4} 1.2 \mathrm{~g}$, and $\mathrm{MgSO}_{4}$ $105 \mathrm{mg}$. Under these conditions, our check test showed a production of $7.68 \mathrm{mU} / \mathrm{g}$ of feruloyl esterase.

Water activity (Aw) determines the type of microorganism that can grow in solid-state fermentation, as well as the metabolic production or excretion of a microorganism [15]. The $R$ value listed in Table 5 shows that water content was the second most important factor for enzyme production. 
TABLE 6: Feruloyl esterase activity based on different sources of plant cell walls.

\begin{tabular}{llccc}
\hline & & \multicolumn{2}{c}{ Feruloyl esterase activity from different carbon source $(\mathrm{mU} / \mathrm{g})$} \\
& Wheat bran & Maize bran & Sugarcane bagasse & Wheat bran + maize bran \\
\hline Wheat bran & $3.8 \pm 0.08^{*}$ & $2.77 \pm 0.07$ & $1.47 \pm 0.05$ & $7.68 \pm 0.09$ \\
Maize bran & $2.80 \pm 0.08$ & $3.65 \pm 0.09$ & $0.87 \pm 0.07$ & $6.32 \pm 0.13$ \\
Sugarcane bagasse & $0.56 \pm 0.06$ & $1.23 \pm 0.07$ & $1.35 \pm 0.07$ & $4.53 \pm 0.15$ \\
\hline
\end{tabular}

${ }^{*}$ means $\pm \mathrm{SD}, n=3$.

3.4. Activity of Feruloyl Esterase Produced on Different Carbon Sources with Different Plant Cell Wall Composition. Table 6 shows that the highest activity of feruloyl esterase was obtained against the same carbon source used for production of the enzyme. In other words, enzymes produced from fermentation on wheat bran, maize bran, or sugarcane bagasse showed highest ferulic acid release from wheat bran, maize bran, or sugarcane bagasse, respectively. However, the enzymes produced from mixtures of carbon sources showed high activity for whichever substrates the cultures contained, indicating an advantage for use of mixture carbon sources for production of FAE.

\section{Conclusions}

The highest activity of feruloyl esterase was produced from A. niger on wheat bran as a solid culture substrate at $72 \mathrm{~h}$ and $36^{\circ} \mathrm{C}$. Addition of maize bran and $\left(\mathrm{NH}_{4}\right) \mathrm{SO}_{4}$ as a nitrogen source could significantly increase enzyme production. The optimal conditions were carbon source to water $1: 1$, maize bran to wheat bran $1: 2,\left(\mathrm{NH}_{4}\right) \mathrm{SO}_{4} 1.2 \mathrm{~g}$, and $\mathrm{MgSO}_{4} 70 \mathrm{mg}$. Under these conditions, feruloyl esterase with activity of $7.68 \mathrm{mU} / \mathrm{g}$ was obtained. The feruloyl esterase produced on a mixed carbon source showed high activity against the plant cell walls that the cultures contained.

\section{Acknowledgment}

The authors appreciate the Department of Education of Guangdong Province for supporting this research Project (cgzhzd0709).

\section{References}

[1] E. Topakas, C. Vafiadi, and P. Christakopoulos, "Microbial production, characterization and applications of feruloyl esterases," Process Biochemistry, vol. 42, no. 4, pp. 497-509, 2007.

[2] C. Vafiadi, E. Topakas, P. Christakopoulos, and C. B. Faulds, "The feruloyl esterase system of Talaromyces stipitatus: determining the hydrolytic and synthetic specificity of TsFaeC," Journal of Biotechnology, vol. 125, no. 2, pp. 210-221, 2006.

[3] I. Benoit, D. Navarro, N. Marnet et al., "Feruloyl esterases as a tool for the release of phenolic compounds from agroindustrial by-products," Carbohydrate Research, vol. 341, no. 11, pp. 1820-1827, 2006.

[4] J. P. Rosazza, Z. Huang, L. Dostal, T. Volm, and B. Rousseau, "Biocatalytic transformations of ferulic acid: an abundant aromatic natural product," Journal of Industrial Microbiology, vol. 15 , no. 6 , pp. 457-471, 1995.
[5] S. Tapin, J. C. Sigoillot, M. Asther, and M. Petit-Conil, "Feruloyl esterase utilization for simultaneous processing of nonwood plants into phenolic compounds and pulp fibers," Journal of Agricultural and Food Chemistry, vol. 54, no. 10, pp. 3697-3703, 2006.

[6] P. Yu, J. J. McKinnon, D. D. Maenz, A. A. Olkowski, V. J. Racz, and D. A. Christensen, "Enzymic release of reducing sugars from oat hulls by cellulase, as influenced by Aspergillus ferulic acid esterase and Trichoderma xylanase," Journal of Agricultural and Food Chemistry, vol. 51, no. 1, pp. 218-223, 2003.

[7] N. M. Anson, E. Selinheimo, R. Havenaar et al., "Bioprocessing of wheat bran improves in vitro bioaccessibility and colonic metabolism of phenolic compounds," Journal of Agricultural and Food Chemistry, vol. 57, no. 14, pp. 6148-6155, 2009.

[8] K. G. Johnson, M. C. Silva, C. R. Mackenzie, H. Schneider, and J. D. Fontana, "Microbial degradation of hemicellulosic materials," Applied Biochemistry and Biotechnology, vol. 20-21, no. 1, pp. 245-258, 1989.

[9] W. Zeng and H. Z. Chen, "Air pressure pulsation solid state fermentation of feruloyl esterase by Aspergillus niger," Bioresource Technology, vol. 100, no. 3, pp. 1371-1375, 2009.

[10] T. Koseki, K. Takahashi, S. Fushinobu et al., "Mutational analysis of a feruloyl esterase from Aspergillus awamori involved in substrate discrimination and $\mathrm{pH}$ dependence," Biochimica et Biophysica Acta, vol. 1722, no. 2, pp. 200-208, 2005.

[11] T. Koseki, K. Mihara, T. Murayama, and Y. Shiono, "A novel Aspergillus oryzae esterase that hydrolyzes 4-hydroxybenzoic acid esters," FEBS Letters, vol. 584, no. 18, pp. 4032-4036, 2010.

[12] G. Mukherjee, R. K. Singh, A. Mitra, and S. K. Sen, "Ferulic acid esterase production by Streptomyces sp," Bioresource Technology, vol. 98, no. 1, pp. 211-213, 2007.

[13] R. P. de Vries, P. A. vanKuyk, H. C. M. Kester, and J. Visser, "The Aspergillus niger faeB gene encodes a second feruloyl esterase involved in pectin and xylan degradation and is specifically induced in the presence of aromatic compounds," Biochemical Journal, vol. 363, no. 2, pp. 377-386, 2002.

[14] K. Jernejc and M. Legiša, "A drop of intracellular pH stimulates citric acid accumulation by some strains of Aspergillus niger," Journal of Biotechnology, vol. 112, no. 3, pp. 289-297, 2004.

[15] R. R. Singhania, A. K. Patel, C. R. Soccol, and A. Pandey, "Recent advances in solid-state fermentation," Biochemical Engineering Journal, vol. 44, no. 1, pp. 13-18, 2009. 

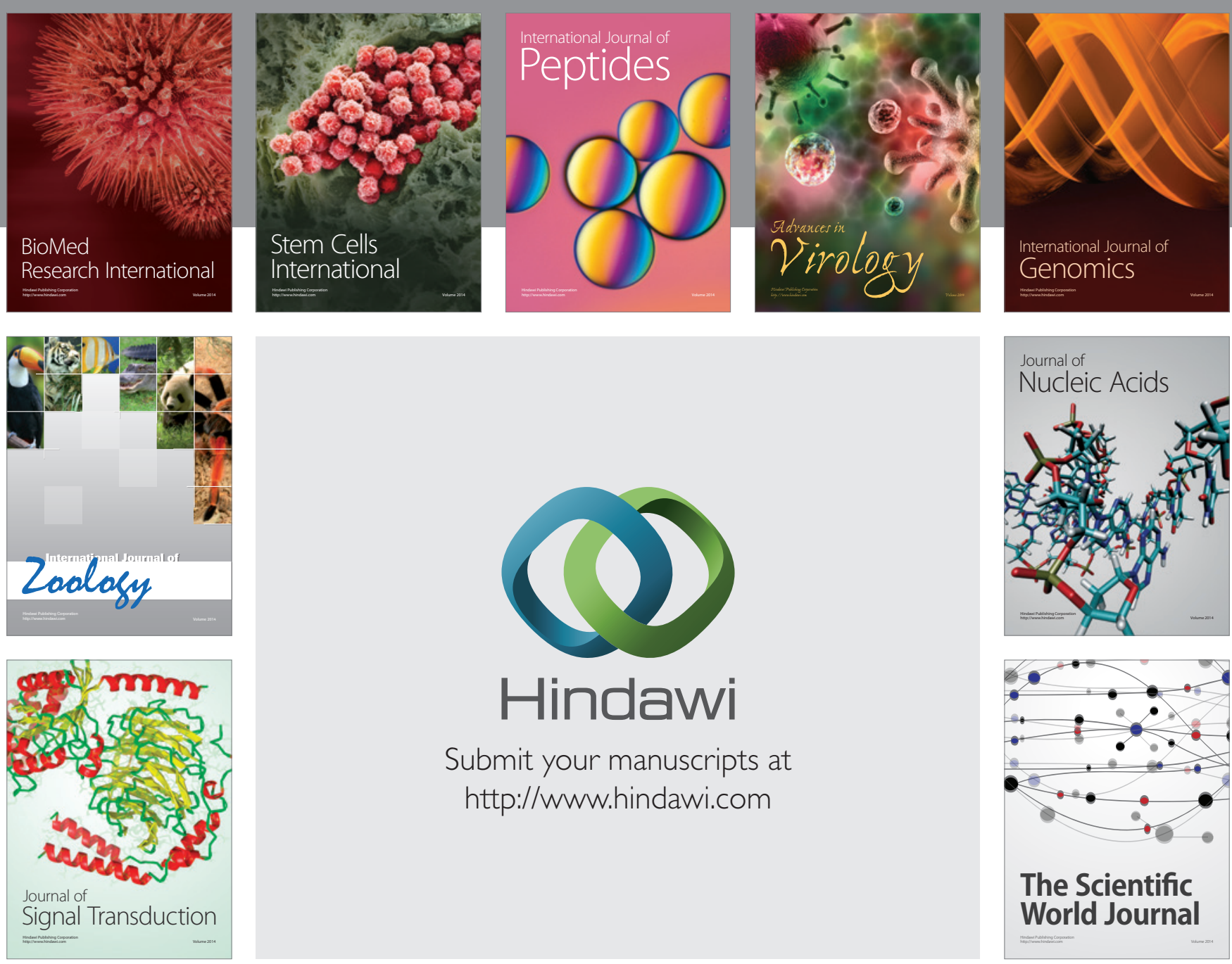

Submit your manuscripts at

http://www.hindawi.com
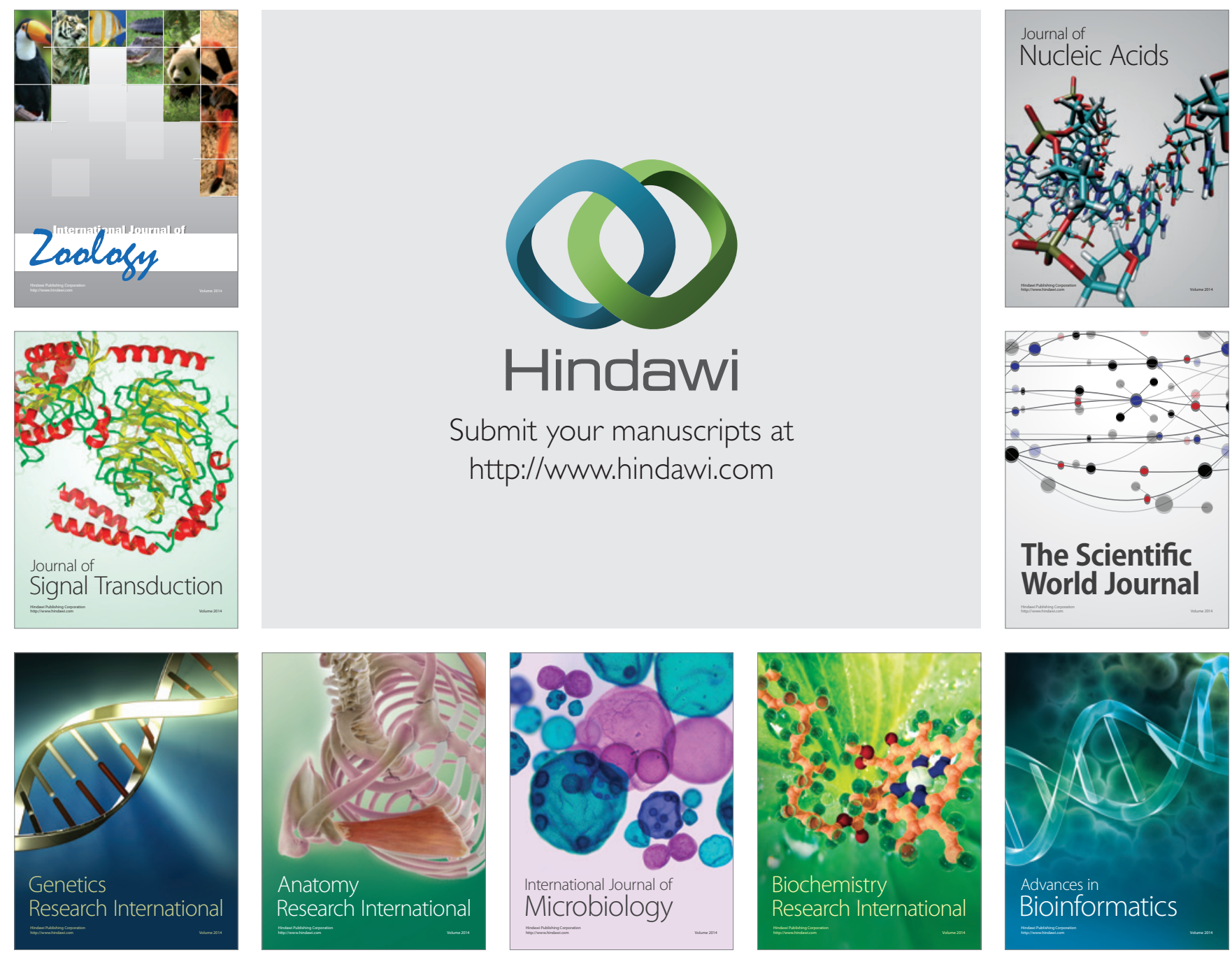

The Scientific World Journal
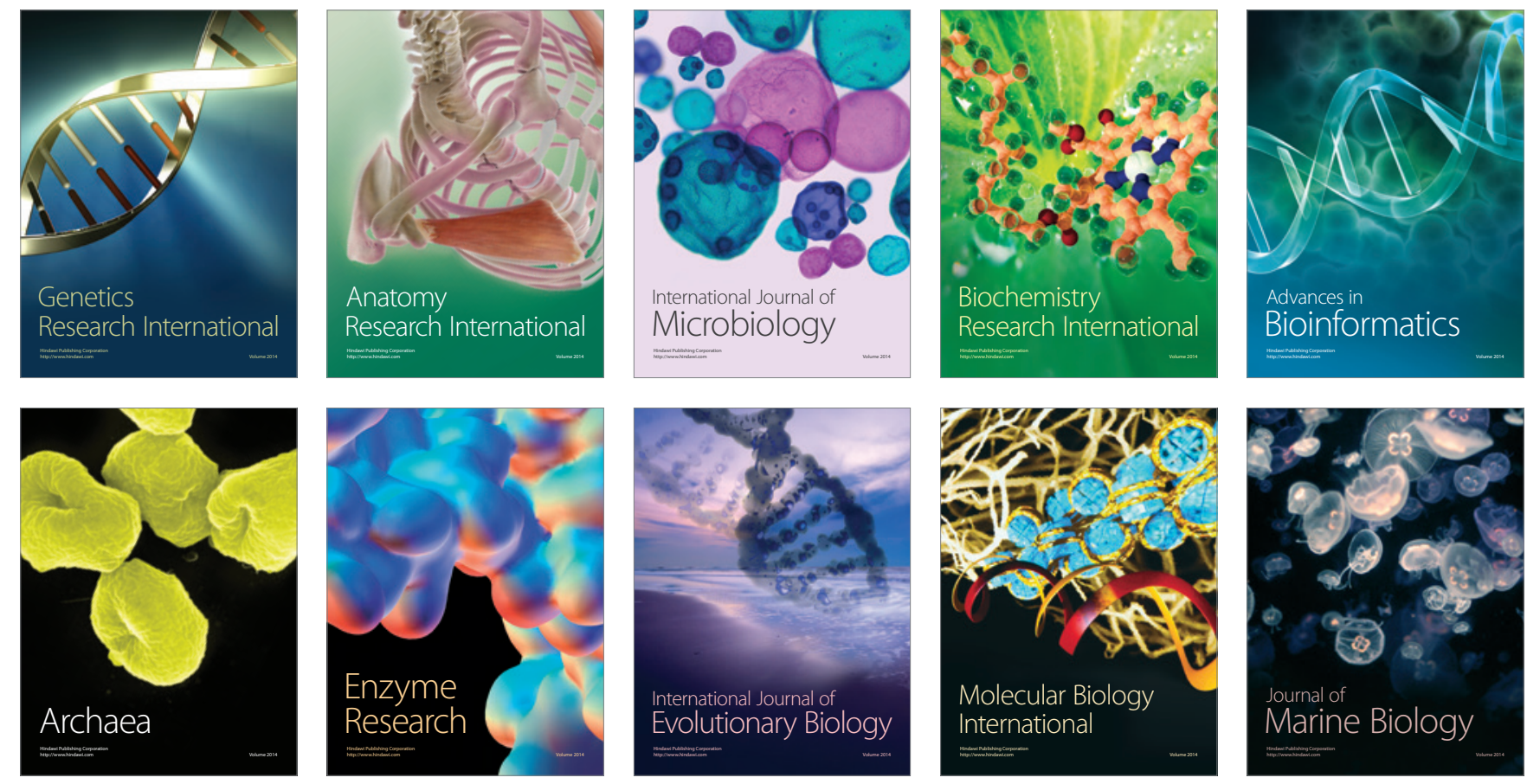